\title{
Kønsforskning og mainstreaming
}

\section{Mainstreaming som differentieret ligefordelingspolitik}

\section{Af Iris Rittenhofer}

\section{Karen Sjørup har anført, at Cmainstreaming som be-} greb i det danske sprog er indholdstomt. ${ }^{1}$ Det betragter jeg ikke som et problem, men som en mulighed for at give begrebet et indhold. Det er op til os at gribe chancen og definere begrebet. I denne artikel vil jeg søge at give begrebet mainstreaming et sådant indhold. Det indebærer, at jeg afgrænser begrebet mainstreaming i forhold til allerede eksisterende betydninger samt i forhold til begrebet ligestilling $\mathrm{i}$ betydningen forskelspolitik. Desuden vil jeg introducere differentieret ligefordelingspolitik som et konkret politisk begreb, der er et resultat af mainstreaming-tankegangen. Jeg diskuterer differentieret ligefordelingspolitik som en model, der både sigter mod en ligefordeling af kvinder og mænd i forskningen samt mod en styrkelse af kønsforsknin- gen. ${ }^{2}$ Med udgangspunkt i bl.a. eksisterende norske og tyske praktiserede modeller, introducerer jeg afslutningsvis to konkrete initiativer, der sigter mod en differentieret ligefordelingspolitik på universiteterne, og som jeg anser for at være meget relevante for en effektiv implementering af mainstreaming på universiteterne.

\section{Hvad er mainstreaming?}

Begrebet mainstreaming bliver allerede i dag brugt i to konkrete betydninger. Mainstreamingbegrebet er søgt 'mainstreamet', dvs. begrebet bruges om kvindeforskningens gamle strategi om at integrere kvinde- og kønsforskningen i de eksisterende fag og fagområder. Dette mainstreamede begreb sælger en gammel strategi i nye klæder. Men jeg mener ikke, at mainstreaming har noget at gøre med denne integrationsstrategi. Det samme kan siges om mainstreaming og ligestilling. Mainstreaming betyder heller ikke at 'mainstreame' ligestilling. Begrebet ligestilling er fortsat meget uklart, som det også fremgår af betænkningen udarbejdet af kommissionen for det fremtidige ligestillingsarbejde.

Mainstreaming er både en chance for at rette op på eksisterende kønsskævheder, og en chance for kønsforskningen. I modsxtning til integrationsstrategierne betyder mainstreaming, at man skal tænke køn ind i alle samfundsmæssige, kulturelle og økonomiske sammenhænge. Mainstreaming betyder i min tolkning, at man skal analysere, hvordan kønsskævheder skabes i deres respektive kontekster og undersøge, om alle planlagte tiltag har samme konsekvenser for begge køn, inden man gennemfører dem i den planlagte form. Har de ikke det, bør man ændre de planlagte tiltag, således at de ikke kommer til at reproducere de relationer, der medfører eksisterende uligheder, ligesom man bør udarbejde målsætninger og handlingsplaner for at rette op på eksisterende skævheder.

Mainstreaming betyder, at man netop tager udgangs- 
punkt i, at køn består i en mangfoldighed af forskellige kontekstafhængige relationer, der konstant skabes og genskabes. Her adskiller mainstreaming sig på to punkter fra ligestillingspolitikken. I modsætning til mainstreaming er ligestillingspolitik for det første en forskelspolitik. Ligestillingspolitik er forskelspolitik, idet den tager udgangspunkt i to køns uforanderlige forskellighed og interne homogenitet. Den sigter mod en opvurdering af kvinders egenart, som denne defineres i sociologiske, biologiske, historiske eller andre fagtermer. Mainstreaming indebærer for det andet, at man ikke kan tage udgangspunkt i generaliseringer om kønnet og dets betydninger. I stedet for at generalisere og universalisere køn, tager mainstreaming udgangspunkt i, hvordan køn skabes og genskabes i den konkrete kontekst.

Mainstreaming betyder derfor, at vi er nødt til at fokusere på de enkelte universiteter, fakulteter, institutter, afdelinger og centre. Fokus må være på, hvordan kønsskævheder konkret produceres og reproduceres. Kønsskævheder som f.eks. kønnenes ulige fordeling på universitetsstillinger eller på fagområder, er skabt og reproduceres i et samspil mellem mangfoldige relationer. Med det in mente vil jeg i det følgende diskutere mainstreaming-begrebet med udgangspunkt i en række eksempler fra forskningen og universitetsverdenen. Men først vil jeg uddybe, hvad jeg mener med, at ligestillingspolitik er forskelspolitik.

\section{Ligestilling: \\ Hvad er problemet?}

Mainstreamingstrategien, der via $\mathrm{FN}^{3}$ og $\mathrm{EU}$ omsider er nået til Danmark, indebærer for mig en tiltrængt politisk nytænkning. Det er en chance for, at en ligestillingspolitik i betydningen forskelspolitik kan afløses af noget nyt. Hvad er det så, jeg forstår ved forskelspolitik? Jeg vil illustrere det med et eksempel.

Hvis man f.eks. går ud fra, at man opnår en højere andel kvinder i universitetsstillinger ved at gøre det til et krav, at der ud over forskningsmæssige kvalifikationer skal lægges vægt på sociale færdigheder, personlige egenskaber og formidlingsevne ${ }^{4}$, så betyder det for mig at se, at man tager udgangspunkt i kønnenes forskellighed, hvor kvinder som et køn antages at have nogle evner, mænd som et andet køn ikke antages at have. Man tænker i polariseringer, og man tager som det selvfølgelige udgangspunkt at universitetet er et mandeuniversitet, hvor mændene som et køn antages at være kvalificerede, men hvor kvinderne kan supplere universitetet med nogle særlige (kvindelige, forstås!) egenskaber. Set ud fra den eksisterende strukturelle kønsarbejdsdeling i samfundet må man gå ud fra, at kvinder, hvis denne strategi forfølges, qua deres køn, nu også skal forpligtes på og begrænses til at være universiteternes pædagoger. Hvad man i bedste fald vil kunne opnå er nicher for nogle kvinder, men ikke, at kvinder får lige vilkår. Bl.a. vil vi med rimelighed kunne forvente, at disse nicher ikke opnår en høj prioritering ved fordeling af forskningsmidler. Dermed reproduceres én af årsagerne til de eksisterende kønsskævheder: at et stort antal kvinder allerede $\mathrm{i}$ dag befinder sig i områder, hvor der mangler både stillinger og forskningsmidler. ${ }^{5}$ For det andet tager forslaget ikke højde for kønsskævhedernes forskellige udformninger på de forskellige fagområder og fag. Ej heller tages der hensyn til, at der jo rent faktisk findes kvinder - om end for få - i 'ordinære' universitetsstillinger. Samlet har det syn på køn, som gemmer sig i forslagets skjulte præmisser, den uheldige og utilsigtede bivirkning, at det er med til at retfærdiggøre og dermed reproducerer det, den både forventer at finde $o g$ samtidig egentlig ønsker at afskaffe: et kønspolariseret universitet.

Et andet problem med ligestillingspolitikken i dens eksisterende udformning er, at det er en politik, hvor ligestillingsinitiativer er målsætningen i sig selv. Det, vi mangler, er en klar målsætning for ligestillingspolitikken, og det skyldes bl.a. uklarheder omkring ligestillingsbegrebet. Det meget uafklarede spørgsmål er: Hvad er det, vi vil opnå? Problemet kan illustreres med det for os alle velkendte fænomen, at hvis der er 30\% kvinder indenfor et fag, så snakker man om en succes og ligestilling. Men hvis vi har $40 \%$ kvinder i et fag, så taler vi om kvindedominans og en farlig udvikling, og man begynder at overveje, hvad der kan og skal gøres for at vende denne udvikling. 
Differentieret ligefordeling: et alternativ til ligestilling Mainstreaming som en strategi kan danne grundlag for en politik, der ikke tager udgangspunkt $i$ en generaliserende forestilling om kønnenes forskellighed, og kan med fordel afløse en forskelspolitik. Ligestillingspolitikken bør afløses af det, jeg her vil betegne som en

\section{Tilhørere ved Konsforskningsfestivalen.}
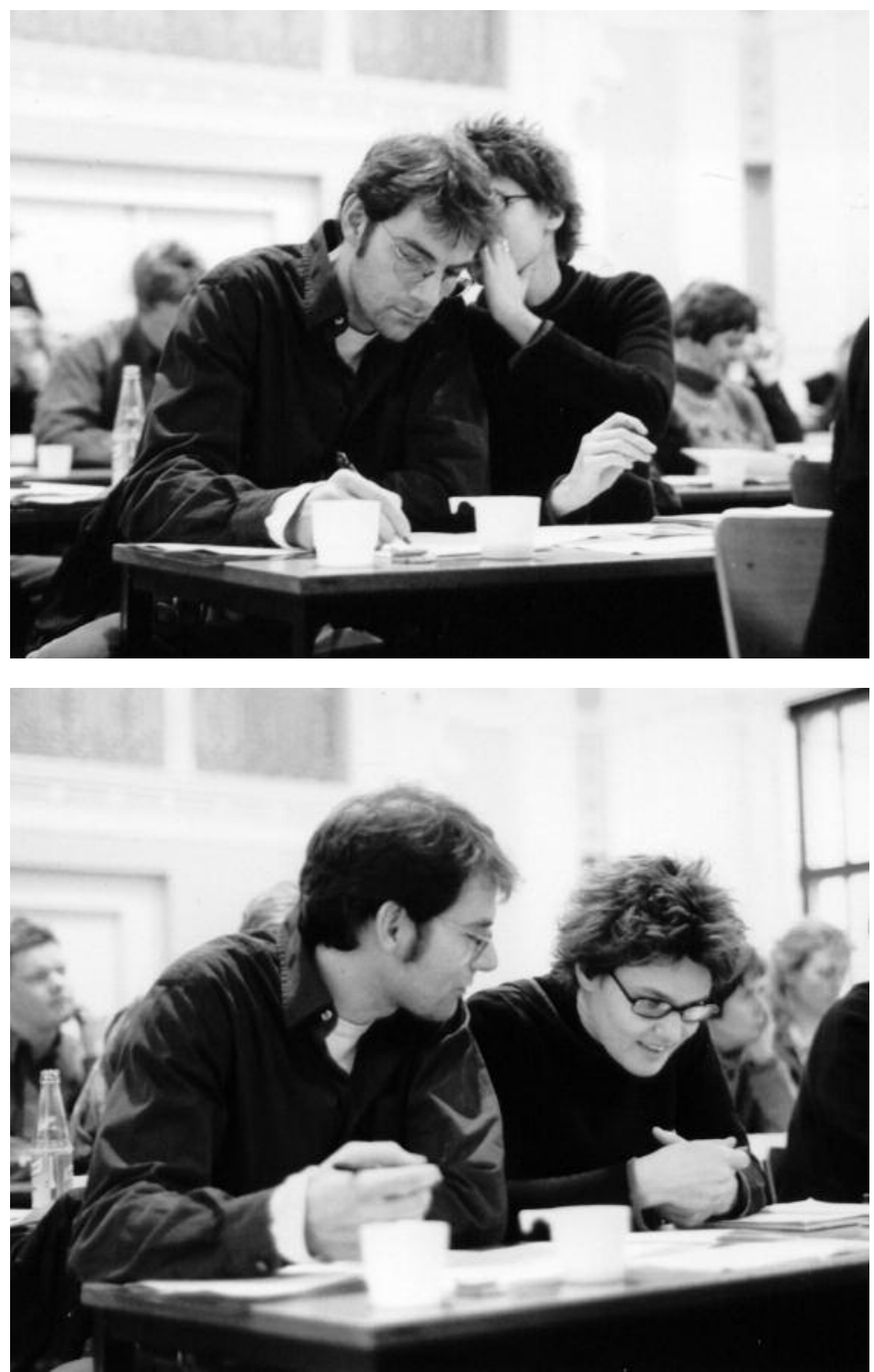

differentieret ligefordelingspolitik. Differentieret ligefordelingspolitik tager udgangspunkt i, hvordan køn i sine mangfoldige udformninger skabes og genskabes afhængigt af og i menneskelige relationer i konkrete kontekster. En differentieret ligefordelingspolitik er et alternativ til ligestilligspolitik. Den kan udspringe som

et handlingsorienteret resultat af mainstreaming-tilgangen.

Mainstreaming af køn er ikke en målsxtning i sig selv. Mainstreaming af køn medfører handling på flere trin: Analyser af de eksisterende kønsskævheder på de enkelte universiteter, fakulteter, institutter, centre, afdelinger, fag etc. samt analyser af de konsekvenser, tiltag ville have med blik på at skabe eller at reproducere og dermed manifestere eksisterende forhold, der resulterer i kønsskævheder. Analyserne kan følges op med udviklingen af strategier og forhandlinger af konkrete målsætninger for en ligefordeling af køn på de enkelte områder samt en formulering af handlingsplaner, der skal kunne føre til en opnåelse af målsætningerne indenfor et aftalt tidsrum. En differentieret ligefordelingspolitik medfører, at man tager initiativer for at opnå konkrete målsætninger. Målsætningerne er selvfølgelig genstand for forhandlinger, det vender jeg tilbage til. Sådanne målsætninger fulgt op af konkrete handlingsplaner er en afgørende forudsætning for at gennemføre en effektiv kønspolitik.

Afgørende for mainstreaming-tankegangen er en differentieret kønspolitik. Her tager vi ikke udgangspunkt i kønnenes selvfølgelige forskellighed. Vi tager det heller ikke for givet, at kønsskævheder er udtryk for denne forskellighed eller for en nedvurdering af det "kvindelige". 'Kvindelig' er ikke en egenskab ved køn. 'Kvindelig' er en kulturel bestemt betegnelse for det, der i en konkret historisk kontekst i 
forvejen ikke regnes for at være betydningsfuldt, værdifuldt eller prestigefyldt. ${ }^{6}$ Fag eller brug af bestemte metoder og teorier făr ikke deres prestige af, at det mest er mænd, der befinder sig i eller benytter sig af dem, for ikke alle faglige specialiseringer, hvor der er flest mænd, har høj prestige. ${ }^{7}$ Ligeledes er det kunstige skel mellem teoretisk/abstrakt og empirisk/konkret forskningsarbejde hverken et spørgsmål om kønnenes eller fagenes forskellighed. ${ }^{8}$ Betegnelsen 'mandlig' både naturaliserer og legitimerer områders eller fags videnskabelige betydningsfuldhed og disses bevarelse. Relationen er kulturel, ikke essentiel og ligeledes historisk foranderlig. ${ }^{9}$ Den er del af vores forståelser af, hvilke menneskelige relationer der består, og af deres karakter. Mainstreaming betyder at vi ser på, hvordan videnskabelig prestige skabes, hvordan det udmønter sig i kønsskævheder, og hvordan disse skævheder konsolideres på hvert enkelt fagområde, fag, eller i faglige specialiseringer.

\section{Politikernes rolle}

Politikerne, og ikke mindst ligestillingsministeren, kan her spille en afgørende rolle. De kan bidrage til, at mainstreaming tages alvorligt som strategi, at det er forpligtende for universiteterne at tænke køn ind på alle planer, og at der udvikles konkrete handligsplaner for, hvordan man kan rette op på skævhederne, hvad målsætningerne er, hvordan man vil nå disse målsætninger og indenfor hvilket tidsrum. Målsætningerne og tidsrummet for at opnå disse målsætninger kan være genstand for forhandlingerne mellem ligestillingsministeren og forskningsministeren på den ene side og de enkelte universiteter på den anden side.

Derudover mener jeg at forskningsministeren kan spille en afgørende rolle for en effektiv mainstreamingspolitik ved at styrke kønsforskningen. Et bidrag fra politikernes side til at styrke en differentieret ligefordelingspolitik kræver, at denne politik bygges på de eksisterende metodiske og teoretiske landvindinger i kønsforskningen. Det forudsætter, at kønsforskningen styrkes.

\section{Kønsforskning og mainstreaming}

Jeg ser mainstreaming-politik som en direkte konsekvens af den nytænkning, der har fundet sted indenfor den teoretiske og metodiske grundforskning i kønsforskningen siden slutningen af 1980erne, nemlig udviklingen af ikke-essentialistiske, differentierede, mangfoldige, ikke dualistiske og relationelle kønsforståelser. Mainstreaming-kravet kan på den baggrund ses som en konsekvens af kønsforskningens teoretiske og metodiske udviklinger. Udviklingen af mainstreamingstrategien peger på, at både den teoretiske forskning og kulturforskningen er nyttige og politisk relevante. For at referere til den talmagi, der så flittigt blev brugt omkring nytårsaften 1999/2000 vil jeg sige, at kvindeforskning og ligestillingspolitik hører sammen som tiltag, der tilhører ikke bare det sidste århundrede, men faktisk det sidste årtusinde. Dertil hører en politik rettet mod "mændene”, hvor man søger at få opvurderet og favoriseret det såkaldt genuint "kvindelige", en politik, der udspringer fra 1970erne og som utvivlsomt også havde sin berettigelse dengang. Det nye årtusinde tilhører kønsforskningen og mainstremingen, med en differentieret ligefordelingspolitik som fremtidens politiske tiltag.

Kønsforskningen har oparbejdet en betragtelig ekspertise i at tænke køn ind i alle tænkelige og især utænkelige sammenhænge. Kønsforskningen har genereret en lang række metoder til at analysere og forstå de komplekse relationer, vi kalder køn. Kønsforskning er med andre ord en forudsæetning for at kunne sætte ord på de kønnede relationer i forskningssystemet. ${ }^{10}$ Faget kønsforskning er derfor en nødvendig og eksistentiel forudsætning for med succes at kunne gennemføre en differentieret ligefordelingspolitik og dermed en succesfuld implementering af mainstreaming-tankegangen.

Anvendt forskning og ekspertise kræver et metodisk og teoretisk grundlag. Lige så lidt som anden viden er kønsforståelser kontekstuafhængige, neutrale og uforanderlige. ${ }^{11}$ Man kan ikke lave en kønspolitik uden at tage højde for forskningens teoretiske og metodiske landvindinger og uden en forskning, der har mulighed for at arbejde videre med at udvikle teorier og metoder.

Kvindeforskningens integrationspolitik har bidraget til, at 
der i dag findes kønsforskere i en mangfoldighed af institutionelle sammenhæng og fag, hvor kønsforskningen drives. Men denne politik har også haft den uheldige konsekvens, at kønsforskningen i dag snarere har status som en oftest perifert placeret faglig specialisering fremfor som en anerkendt selvstændig disciplin, som det er tilfældet i mange andre lande. Kønsforskning har i dagens Danmark slet ikke status som et selvstændigt fag; centrene for kvinde- og kønsforskning befinder sig i dag i en truet situation, hvad angår økonomi og stillingsstruktur. Integrationspolitikkens uheldige bieffekt har været, at kønsforskere er tvunget til at søge ly $i$ andre fag med den konsekvens, at kønsforskningen bliver til et aspekt af, men ikke til det centrale indhold i, forskerens daglige arbejde. Det sker bl.a. på bekostning af fagets teoretiske og metodiske udvikling. Kønsforskningens status som hjælpevidenskab har desuden ført til den kedelige misforståelse, at man tit identificerer kvindeog kønsforskning med ligestilling, samt at ligestilling som politisk krav kun legitimerer en del af kønsforskningen og er med til at fastholde dens status som specialisering og hjælpevidenskab.

For at illustrere kønsforskningens aktuelle situation med et billede: Lad os forestille os, at man udsulter og opløser institutterne for matematik med den begrundelse, at matematik som hjxlpevidenskab jo er integreret i en række andre fagområder så som biologi, historie, sociologi og økonomi, hvilket overflødiggør opretholdelsen af selvstændige institutter og stillinger - både rekruteringsstillinger og faste stillinger - for matematikere. Det betyder, at man desuden har den præmis, at matematik er en entydigt definerbar, engang for alle klart afgrænset størrelse, et redskabsfag uden behov for en selvstændig metodisk og teoretisk udvikling - det er ligesom taget for givet, hvad matematik er, hvad den kan og hvordan den skal bruges. På samme måde ligger der både bag kvindeforskningens, men også bag kønsforskningens reduktion den opfattelse, at man roligt kan gå ud fra køn som nogle givne størrelser - ved ikke alle og enhver hvad kvinder og mænd er?

En effektiv mainstreaming-politik i betydningen differentieret ligefordelingspolitik kræver som forudsætning for dens succes en anerkendelse af kønsforskning som et fag. Det kræver en styrkelse af kønsforskningen, både økonomisk og stillingsmæssigt, og her tænker jeg både på grundforskningen og på de empiriske eller mere målforskningsorienterede undersøgelser.

Hvordan kan kønsforskningen som selvstændig disciplin styrkes? En mulighed er at konsolidere og udvide den eksisterende centerstruktur, alternativt ved at oprette centrale centre for kønsforskning. En anden mulighed er oprettelsen af afdelinger eller institutter for kønsforskning. Her kan det vise sig nødvendigt at finde individuelle løsninger ved de enkelte universiteter. Det kan gøres ved at gøre kønsforskning til en karrierevej på lige fod med andre fag, dvs. ved oprettelsen eller konsolideringen af eksisterende uddannelser, ved indførelsen af kandidatuddannelser, ved at skabe flere ph.d-stipendier, ved at indrette adjunkturer for kønsforskere samt ved at oprette lektorstillinger og professorater i kønsforskning. Det er faktisk iøjnefaldende, at Danmark - i modsætning til en lang række andre lande - aldrig har haft et professorat i kønsforskning.

Kønsforskningen har et generationsskifte-problem. Det er ret interessant, at de lektorstillinger, der findes og som blev oprettet under aktionsplanen i begyndelse af 1980erne, er bundet til de personer, der dengang blev udnævnt som lektorer. Stillingerne kan inddrages igen, når vedkommende fratræder sin stilling. Og så kræver det foruden held universiteternes imødekommenhed samt et ret kraftigt stykke benarbejde fra engagerede folk at få stillingen genopslået som lektorater i kønsforskning. Som situationen er i dag, er der ringe muligheder for et generationsskifte i kønsforskningen. Kønsforskningen bør også strukturelt set anerkendes som et fag legitmeret af dens teoretiske, metodiske og empiriske forskningsarbejde. For at kunne konsolideres som et fag skal kønsforskning på alle niveauer have et minimumsantal faste forskerstillinger samt rekruteringsstillinger.

Det bringer mig afslutningsvis ind på de to afgørende spørgsmål med hensyn til universiteterne: Hvordan kan man 
konkret implementere mainstreaming? Hvordan kan man gøre mainstreaming af $k ø n$, kønsforskning og en differentieret ligefordelingspolitik til universiteternes egen interesse?

\section{Forudsætninger for en differentieret ligefordelingspolitik:} To konkrete initiativer

Ud over den rolle, jeg mener politikerne her kan spille, er det en afgørende forudsætning for en effektiv implementering af mainstreaming, at man indfører mainstreaming-sekretariater. ${ }^{12}$ Med udgangspunkt i en differentieret ligefordelingspolitik er det imidlertid ikke nok at en enkelt person placeres tæt på universiteternes ledelse. En sådan politik ville medføre den store risiko, at selve det at have ansat en mainstreaming-sekretær vil blive betragtet som en succes for ligestillingspolitikken, en opfyldelse af et krav om at mainstreame ligestillingsstrategier. Selve ansættelsen ville kunne betragtes som en opnåelse af målsætningen fra universiteternes side. Desuden ville det ikke give den for en differentieret ligefordelingspolitik nødvendige indsigt i, hvad det er, der foregår rundt omkring de enkelte steder på universitetet, og som resulterer i kønsskævheder. Der ville være lagt op til en generaliserende forskelspolitik, men der ville ikke være skabt muligheden for en differentieret ligefordelingspolitik.

En differentieret ligefordelingspolitik kræver en mere differentieret og decentraliseret struktur, som jeg her ikke kan gøre rede for i detaljer. Men jeg vil nævne og skitsere nogle for mig at se centrale elementer. ${ }^{13}$ Ledelsen bør være forpligtet til at dokumentere en effektiv ligefordelingspolitik. Den skal skabe grundlag for at kunne opfylde de målsætninger, der resulterer fra forhandlinger. En mainstreaming-sekretær placeret i eller tæt på ledelsen bør være demokratisk valgt af repræsentanter for alle fire stillingskategorier, samt være indehaver af en fast stilling f.eks. som fuldmægtig. Alternativt kan vedkommende være udlånt f.eks. i fire år og bagefter returnere til den oprindelige stilling som adjunkt, lektor eller professor. Sekretæren skal være ansvarlig overfor rektor og konsistorium samt en mainstreaming-kommission med representanter fra alle områder.

Afgørende er den decentrale struktur. Sekretæren skal have frivillige samarbejdsudvalg eller representanter i hvert fakultet og helst i hvert institut (rådføring, indsigt, insiderinformationer). Mainstreaming-sekretæren skal have sit eget budget at råde over, studentermedhjælper, samt have en vetoret $\mathrm{i}$ bedømmelsesudvalg og i andre personalespørgsmål, f.eks. stillingsopslag. Derudover kunne Koordinationen for kvinde- og kønsforskning udvides til et nationalt koordinerende mainstreaming-sekretariat.

Et centralt spørgsmål angående mainstreaming og universiteterne er spørgsmålet om motivation. En løsning kunne være at gøre mainstreaming til genstand for universiteternes økonomiske interesse. Hvor- dan vækker man universiteternes interesse for mainstreaming i udformningen af en differentieret ligefordelingspolitik? Også her gxlder det, at jeg ikke har mulighed for at gå i detaljer, men jeg kan kort skitsere nogle grundlæggende elementer i, hvordan et sådant system for økonomiske incitamenter kunne se ud. ${ }^{14}$ Også her er det afgørende, at økonomiske incitamenter tilpasses de enkelte universiteter og de forskellige situationer, enkelte fagområder og fag befinder sig i.

En model for økonomiske incitamenter kunne se ud som følger: Som udgangspunkt formulerer man to minimumskrav: et krav om kønsfordelingen blandt de studerende i de enkelte fag og et krav om kønsfordelingen på de enkelte stillingsniveauer. Som et første mål skal kønsfordelingen blandt kandidater afspejle sig i andelen af adjunkter, kønsfordelingen på adjunktniveauet skal afspejle sig i fordelingen af lektorater, og det samme med professorater. I forbindelse med at forpligte universiteterne til at følge handlingsplaner for øget ligefordeling af køn i de enkelte fags stillingsstruktur skal minimumskravene jævnligt udvides og tilpasses de ændrede forhold. Det har bl.a. den fordel, at kønsfordelingen ikke kan fastfryses i f.eks. et 30:70 forhold, men at der løbende over en årrække må arbejdes for at nå frem til en reel ligefordeling.

Systemet kan gøres økonomisk interessant ved f.eks. at knytte krav om kønsfordelingen til taxameterordningen. 
Pointen er, at det ikke skal gå ud over grundbevillingerne, og at det er et belønningssystem. Økonomiske incitamenter for universiteter går ud på at indføre et økonomisk belønningssystem for dem, der arbejder for samt opnår den ønskede målsætning om kønnenes ligefordeling eller som kan dokumentere en positiv udvikling $\mathrm{i}$ denne retning. Dem, der ikke gør en indsats eller realiserer målsætningerne, får øremærket en del af deres budget/bevillinger til at finansiere en aktiv differentieret ligefordelingspolitik.

Fordelene ved systemer for $ø$ konomiske incitamenter er mange. Systemerne kan kompensere det underrepræsenterede køn for strukturelle ulemper. Derudover kan mainstreaming hermed gøres til universiteternes egen interesse, ligeledes det at finde frem til årsager for kønsskævheder samt udarbejdelsen af handlingsmuligheder. Diskussionen om kønsfordelingen i stillingerne kobles af diskussionen om kønsfordelingen i de enkelte fag - det giver en stor chance for at afessentialisere kønnede forklaringer af strukturelle misforhold og for i stedet at synliggøre og diskutere de usynlige, underforståede præmisser i forskningsprioriteringer og deres konsekvenser for kønsfordelingen. ${ }^{15}$ Man tager højde for en differentieret kønsforståelse og sørger bl.a. for, at pengene anvendes der, hvor kvinder konkret befinder sig stillingsmæssigt og fagmæssigt. Dermed ville kvaliteten i forskningen kunne forbedres tydeligt - ikke fordi kvinder tilfører særlige kønsspecifikke kvaliteter, men fordi hidtil nedprioriterede fag og faglige specialiseringer ad denne vej ville kunne styrkes, både hvad angår stillinger og forskningsmidler. Desuden kan vi tage højde for at styrke de faglige områder, hvor der findes kvalificerede kvinder, men ingen eller få stillinger eller forskningsmidler. Et differentieret finansieringssystem med bl.a. øremærkede penge kan således til en start sætte ind der, hvor kønnene faktisk befinder sig i uddannelserne og i forskningen $^{16}$ og være medvirkende til at øge kvindernes andel i de videnskabelige stillinger på alle niveauer. Strategierne ville med fordel også kunne diskuteres i forhold til forskningsrådene eller sektorforskningen.

\section{Noter}

1. Jeg refererer til K. Sjørups oplæg ved seminaret Mainstreaming af kønsforskning, 28. januar 2000 i Diamanten, København.

2. Kønsforskning er her forstået meget bredt som et samlingsbegreb, der dækker over både køn, queer theory, etnicitet etc. samt kønsforskere af begge køn.

3. Mainstreaming blev vedtaget som en politisk strategi ved FN's tredje verdenskvindekonference i Nairobi 1985. Ved FNs fjerde verdenskonference ændredes mainstreaming fra en politik, der skulle rette op på kvinders situation i den tredje verden, til en forpligtelse for især regeringer til at indtænke et kønsperspektiv i politik og programmer, inden beslutninger herom træffes. 4. Dette eksempel er taget fra
Rapporten fra Udvalget for Ligestilling i Forskning med titlen 'Ligestilling i Forskning', udgivet af Forskningsministeriet i november 1998.

5. Ifølge Inge Henningsens oplag ved seminaret Mainstreaming af kønsforskning, 28. januar 2000 , i Diamanten i København. Der ligger flere skjulte og ureflekterede forudsætninger i udvalgets forslag, eksempelvis at det udelukkende er kvalifikationer, og oven i købet objektivt definerbare og entydigt målbare kvalifikationer, der er det eneste grundlag for at ansætte universitetsforskere. Bl.a. har E. Bendix (1999) vist, at der er flere - både udtalte og ikke udtalte - bedømmelseskriterier på spil, der ikke har at gøre med 'kvalifikationer'. I. Henningsen (1999) har kunnet dokumentere en række faktorer, der entydigt indikerer, at et stort antal universitetsstillinger målrettet er opslået til én bestemt person, og ikke nødvendigvis til den bedst kvalificerede. Cathrine Hasse har ved et plenumforedrag ved Foreningen for kvinde- og kønsforsknings årskonference i Aalborg i april 1999 gjort opmærksom på, at både kvinder og mænd skal gennemgå en tilpasningsprocess, når de begynder at læse på universitetet. Det indikerer, at der ikke kan være tale om et 'mandeuniversitetet', der kræver nicher for 'det andet køn' eller dets særlige tilpasning.

6. F.eks. Rittenhofer (1999, 1999a).

7. F.eks. I. Henningsens oplæg under Mainstreamingseminaret. Ligeledes Rittenhofer (2000a), der viser, at fagområder og fag, der udelukkende sættes i forbindelse med mænd, kan have lav 
prestige. Køn er ikke blandt de relationer, der er med til at skabe et fagområdes betydningsfuldhed; og køn er ikke den eneste kategori, der konsoliderer eksempelvis områdernes prestige. 8. En foreløbig sammenligning af mit eget projekt (Rittenhofer 1999a) med Birte Kloch Frederiksens (2000) viser, at denne skelnen bruges både til at skabe et hierarki af betydningsfuldhed mellem fag eller fagområder samt indenfor fag som f.eks. ingeniørvidenskab, der i de almene forskningsdiskurser har status som udelukkende ikke-boglært og praktisk orienteret. Det betyder, at både kønnenes og fagenes specifikke karakteristika er italesættelser og legitimerende naturaliseringer af konkurrerende opfattelser af den videnskabelige forsknings væsen, betingelser og formål (se Rittenhofer 1999a).

9. Det gxlder også for en anden elite, nemlig erhversledere. F.eks. Rittenhofer (2000).

10. Nødvendigheden af at sætte ord på køn ved f.eks. bedømmelsesprocedurer dokumenteres i Bendix (1999).

11. Viden om køn er ligesom al anden viden situeret. Begrebet "situated knowledge" kommer fra Donna Harraways artikel "Situated Knowledges”, i Haraway (1991): Simians, Cyborgs and Women.

12. Af indlysende grunde er jeg ikke glad for begrebet 'ligestillingskonsulent'. 'Mainstreamingsekretær' er et forsøg på at nå frem til et begreb, der svarer til en differentieret ligefordelingspolitik.

13. Disse centrale elementer har jeg udarbejdet med udgangspunkt i mit kendskab til især tyske og norske initiativer.
14. Elementerne er hentet fra forskellige modeller, der er gennemført på en række tyske universiteter. Jeg arbejder for tiden på en artikel, hvor jeg mere detaljeret præsenterer og diskuterer de enkelte modellers udformning: Økonomiske incitamenter og differentieret ligefordelingspolitik ved danske universiteter (arbejdstitel).

15. De usynlige og selvfølgelige præmisser, der ligger til grund for forskningsprioriteringer søges analyseret, historiseret og konkretiseret i mit igangværende projekt. Se f.eks. Rittenhofer 1999a.

16. Som eks. på hvordan kønnene fordeler sig på fag eller faglige specialiseringer se Henningsen (1998a, 1998).

\section{LITTERATUR}

- Bendix, E. (1999): Køn, virksombed \& kompetence. Køn i den akademiske organisation, arbejdspapir nr. 6. Redigeret af I. Henningsen. Institut for Statskundskab, Københavns Universitet.

- Frederiksen, Birte Kloch (2000): Den verdensfjerne viden$s k a b$ ? Kønsbarrierer i de højere uddannelser og i forskningen. Arbejdspapir VCL-serien nr. 6. Videncenter for Læreprocesser, Aalborg Universitet.

· D. Haraway (1991): Simians, Cyborgs and Women, Free Association Books, London.

- Henningsen, I. (1998): Lagevidenskab og køn. Køn i den akademiske organisation, arbejdspapir nr. 2. Redigeret af I. Henningsen. Institut for Statskundskab, Københavns Universitet.

- Henningsen, I. (1998a): Kønsdifferentierede adgangskrav på overgangen til de lange videregående uddannelser. Køn i den akademiske organisation, arbejdspapir nr. 3. Redigeret af I. Henningsen. Institut for Statskundskab, Københavns Universitet.

· Henningsen, I. (1999): ”Om

kvalifikationer og køn". Kvinder, Køn \& Forskning 1/1999.

- Rittenhofer, I. (1999): Diskurs und Konstruktion. Die dänischen und deutschen Medienprösentationen der Führungsdebatten 1960 - 1990. Eine vergleichende geschlechterhistorische Analyse. Skrifter udgivet ved institut for Samfundsudvikling og Planlægning, Aalborg Universitet.

- Rittenhofer, I. (1999a): Askepot bager luksuskringle. Kønsbarrierer i de højere uddannelser og i forskningen. Arbejdspapir VCLserien nr.l, Videncenter for Læreprocesser, Aalborg Universitet.

- Rittenhofer, I. (1999b): ”En forening for kvinder eller en forening for kønsforskning?” Kvinder, Kon \& Forskning nr.

4/1999.

- Rittenhofer, I. (2000): Historicizing the Glass-Ceiling. The Danish and German leadership debates in the media 1960 - 1989. FREIA's paper series no. 46 , forår 2000. FREIA, Aalborg Universitet.

- Rittenhofer (2000a): 1975 1982. Delrapport 2 (arbejdstitel). Kønsbarrierer i de højere uddannelser og i forskningen. Arbejdspapir, VCL-serien. Under udarbejdelse.

Iris Rittenhofer, ph.d. Forskningsadjunkt 


\section{Er mainstreaming relevant i forskningen?}

\section{Af Drude Dahlerup}

M ainstreaming er moderne! Men det er uklart, om det er et relevant begreb, når der drejer sig om forskning. Kvindeforskningen og, efter den, kønsforskningen har i mange, mange år kritiseret, at kvinders vilkår og emner som kønsidentiteter, kønsrelationer og kønsstrukturer ikke har indgået i forskning og undervisning på universiteter og læreanstalter.

Da jeg begyndte at læse statskundskab i 1963 var 'kvinder' og 'køn' totalt fraværende i undervisningen. Højst kom kvinder ind $\mathrm{i}$ undervisningen om 'smågrupper', især familien. Vi var et par unge kvindelige studerende, der engang imellem vovede at rejse spørgsmålet, om ikke kvinders vilkår var relevant i denne eller hin problemstilling. Resultater var givet på forhånd: Fnis fra kammeraternes side og velmenende, men ukvalificerede kommentarer fra lærerens side.

Det var først med den nye kvindebevægelse i ryggen, at der kom styrke bag ved kravene. Kritikken blev både politisk og faglig. Politisk handlede det om at bidrage til det at ændre kvindernes vilkår i samfundet fundamentalt. Men kritikken var også en faglig kritik: Hvordan kunne man f.eks. studere udbud og efterspørgsel efter arbejdskraft uden at medtage det faktum, at arbejdsmarkedet var og er kønsopdelt? Hvordan kunne man negligere kvindelige forfatterskaber? Hvordan kan man være totalt blind for kønsstrukturerne i organisationer, i politikken og i samfundet i sin helhed? Også de organisationer, hvor der ingen kvinder er, har jo en kønsstruktur og er præget kulturelt af "enkønnetheden”. En af forklaringerne på kønsblindheden er, at "kvinder" og kønsstrukturerne af forskere og af undervisere var lagt i posen: "naturgivne frnomener".

De dramatiske ændringer i kvindernes stilling og i familieinstitutionen sprængte figuren om det naturlige. Samtidig pressede studerende og yngre forskere på for at ændre undervisningens og forskningens mandsdominans og dens kønsblindhed. I starten blev kvindebevægelsens aktivisme bragt ind på universiteter og læreanstalter. Men samtidig startede et arbejde med at videnskabeliggøre kvinde- og kønsforskningen.

\section{Kvindeforskningscentrene}

I 1980'erne blev der som bekendt oprettet kvindeforskningscenter ved alle danske universiteter. Forud var gået en lang diskussion. I starten var mange kvindeforskere imod, at man skulle lave kvindeforskningscentre, fordi målet jo var at integrere kønsaspektet i fagene overalt. Og ville centrene ikke bidrage til en isolation af den nye forskningsgren? Det var et reelt dilemma mellem integration og autonomi. Imidlertid viste det sig langt vanskeligere at integrere kvinde- og kønsperspektivet på fagene end måske forventet. $\mathrm{Og}$ svært for kvindeforskerne, der var startet med enormt gåpåmod, at få faste stillinger. Derfor blev kvinde- og kønsforskningscentrene oprettet. Det forblev imidlertid et stort problem, at mandlige forskere dengang sjældent læste kvindeog kønsforskningens publikationer.

Centrene bidrog efter min opfattelse aktivt til at udvikle kvinde- og kønsforskningen. Samtidig kom der også gang i forskningen i mange fag - men ganske mange fag fortsatte dog, som om intet var hændt. Kvindeforskningen fik nu støtte fra forskningsrådene, og fra Folketinget kom der hjælp i form af aktionsplanen for kvindeforskningen, godt hjulpet på vej af et netværk mellem kvindeforskerne og kvindelige politikere på tværs af partierne. "Nu har kvindeforskningen fået et blåt stempel, så er det jo noget andet", sagde en af mine tidligere modvillige kolleger til mig dengang.

Det blev i 1980'erne formuleret som det "at gå på to ben", når man satsede på både centre og integrering på fagene. Set i historiens lys må de to strategier siges at have styrket hinanden. Men for dem, der har drevet centrene i årenes løb, har det været et enormt slæb, sommetider i medvind, men mindst lige så ofte i modvind. Samtidig med at kønsforskningscentrene er ved at ændres i den vestlige verden, skyder sådanne centre op overalt i den tredjeverden. Se bare på alle de nye kvindeforskningscentre i Kina.

Resultatet af de første mange vanskelige år har som bekendt været, at kvinde- og kønsforskningen har udviklet sig fra et 
negligeret eller udskældt nyt område til en række blomstrende nye forskningsfelter med mange nye tidsskrifter, afhandlinger, bøger og forskningsprojekter over den ganske verden. Det er utroligt spændende at have været med til det forløb.

\section{Mainstreaming}

Hvis mainstreaming betyder, at kønsforskningen skal integreres på fagene, er det således ingen ny strategi. Men det er sikkert på tide at tage centrenes fremtid op til diskussion i Danmark. De har jo også selv indledt en transformationsproces.

Der er god grund til i dag at stoppe op og spørge, hvorhen kvinde-, køns- og mandeforskningen i dag skal gå, og hvordan den skal organiseres. Derfor er det en fremragende idé med dette reflektions-seminar. Der er på mange måder tale om en ny tid, som vi skal tage bestik af.

Mainstreamingbegrebet kommer fra ligestillingspolitikken. Men uklarheden er stor. Handler mainstreaming om en proces, eller om et resultat? Hvem er mainstreaming-aktørerne i processen, og hvem er det, når målet, mainstreaming, er opnået? Drejer det sig i virkeligheden om det sidste nye fif inden for ligestillingspolitikken, efter at vi først havde en periode med særlige ligestillingsudvalg, og derefter en periode med handlingsplaner for ligestilling? Og nu er mainstreaming den nye strategi, men er det ikke de samme aktører, der skubber på, og den samme modstand, der stadig ikke kan overvindes - bl.a. på grund af ligestillingspolitikkens manglende legitimitet, ikke mindst i Danmark? Fordelene ved mainstreaming er oplagte - hvis det lykkes, at få alle instanser til at arbejde aktivt for ligestilling. Men risikoen ved at nedlægge de organisationer, der har udviklet kompetence og skubbet på er, at tavsheden igen skal brede sig, så der reelt ikke sker noget som helst. Inden for ligstillingspolitikken er mange af den mening, at det $\mathrm{i}$ mange år fremover er nødvendigt, også her, at gå på to ben. Når det gælder kønsforskningens organisering er mainstreamingbegrebet måske relevant - endnu en gang.

Når det gxlder selve forskningen er jeg mere i tvivl om mainstreamingbegrebets og strategiens berettigelse. Køn er ikke relevant overalt i forskningen. Og man kan jo ikke tvinge forskere til at tage køn op. Derimod er det for det første vigtigt, at der findes forskningsmidler til kønsforskningen, og at der opslås stillinger inden for dette kompetenceområde. For det andet er det vigtigt fortsat at udbygge de internationale netværk, ikke mindst de faglige (f.eks. de nordiske og internationale historiker-netværk, de politologiske netværk, juridiske, medicinske etc.). Disse netværk, konferencer og mange samarbejdsprojekter har for mange af os har været utroligt vigtige i vores faglige udvikling.

Kvinde- og kønsforskningen har i mange år lidt under fornemmelsen af at være marginal i universitetssystemet. Sådan har jeg også selv tit følt det. Indtil det gik op for mig, at $\mathrm{i}$ universitetsverdenen føler uendeligt mange forskere og discipliner sig marginale. Der er ingen grund til at betragte kønsforskningen som marginaliseret. Tværtimod er dette en disciplin i rivende udvikling. Teoretisk er udviklingen utroligt spændende, og som altid kommer mange af de nye teorier via ph.d-erne og andre yngre forskere.

\section{Kønsforskningens egen mainstreaming}

Der er i dag sket en spændende udvikling, som man kan kalde kønsforskningens egen mainstreaming. Efter arbejdet med at udvikle kvinde- og kønsforskningens, og senere mandeforskningens egne teorier, som da udelukkende handlede om og måtte handle om netop kønnets betydning, ser man i dag fremtrædende forskning, som skriver sig direkte ind i fagenes centrale problemstillinger. I dag kan vigtige dele af feministisk teori læses som central dele af det obligatoriske pensum. Det er sket inden for litteraturvidenskaben og flere andre humanistiske fag. Inden for samfundvidenskaberne gælder det især inden for såkaldt normativ politisk teori, som i dag igen er blevet et meget populært felt. Lad mig bare nævne Iris Young, Nancy Frazer og Anne Phillips værker, som læses og anvendes langt uden for kønsforskernes kreds. Det er en vigtigt form for "mainstreaming", og det skyldes, at kønsforskerne selv har lukket op for parallellerne mellem kønnets konstruktion og dets betydning på den ene side 
og andre gruppers forhold på den anden, ja, at man ser konstruktionen af kønnet i relation til hele samfundsordenen.

\section{Hvem konstruerer kønsforholdet?}

Det er blevet sagt, at kønsforskerne ved stadig at insistere på kategorierne 'kvinder' og 'mænd' i virkeligheden er med til at cementere de snævre kønsbåse, som man netop ville bort fra. Dette er imidlertid en kritik, der efter min mening forveksler mål og midler.

Målet for al feminisme er at fjerne overdeterminationen af kønnet: at hele ens liv bliver struktureret efter, hvilket køn man har. Den amerikanske historiker Nancy Cott har beskrevet problemets kompleksitet således:

"Feminism asks for sexual equality that includes sexual differences. It aims for individual freedoms by mobilizing sex solidarity. It posits that women recognize their unity while it stands for diversity among women. It requires gender consciousness for its basis yet calls for the elimination of prescribed gender roles."

Nancy Cotts pointe - og det er også min - er, at disse feminismens paradokser hidrører fra kvinders paradoksale situation. Med Nancy Cotts ord kommer det af den paradoksale situation, at kvinder er lig med mænd i art, men ulig i reproduktiv biologi og i konstruktionen af kønnet.

Jeg ville formulere det mere skarpt. Det er ikke feminismen, der konstruerer kønsbåsene. Det er derimod den samfunds- orden, som systematisk reproducerer kønssegregation og kønshierarkier. Feminismen har ikke et fælles mål, en frlles utopi. Men der er en frelles stræben efter individualitet og autonomi, og en fælles modstand mod kønsbåse og kønshierarkier. Midlet er derimod i høj grad at vise, at sætte ord på og forsøge at forklare mekanismer, der reproducerer samfundenes kønsorden. At ophøre med denne italesættelse er blot at bidrage til status quo. Det fra. Det er evident, at en sådan strategi kun ville være til fordel for de hvide i Sydafrika.

Derfor forveksler denne kritik mål og midler. Feminismens mål er at overflødiggøre sig selv. Men hvis man i dagens samfund ophører f.eks. med at sammenkoble køn og løn, ja så ville vi måske ikke engang have opdaget, at lønforskellen mellem kvinder og mænd i en række grupper faktisk er øget igen i de senere år. Det kunne jo være yndigt!

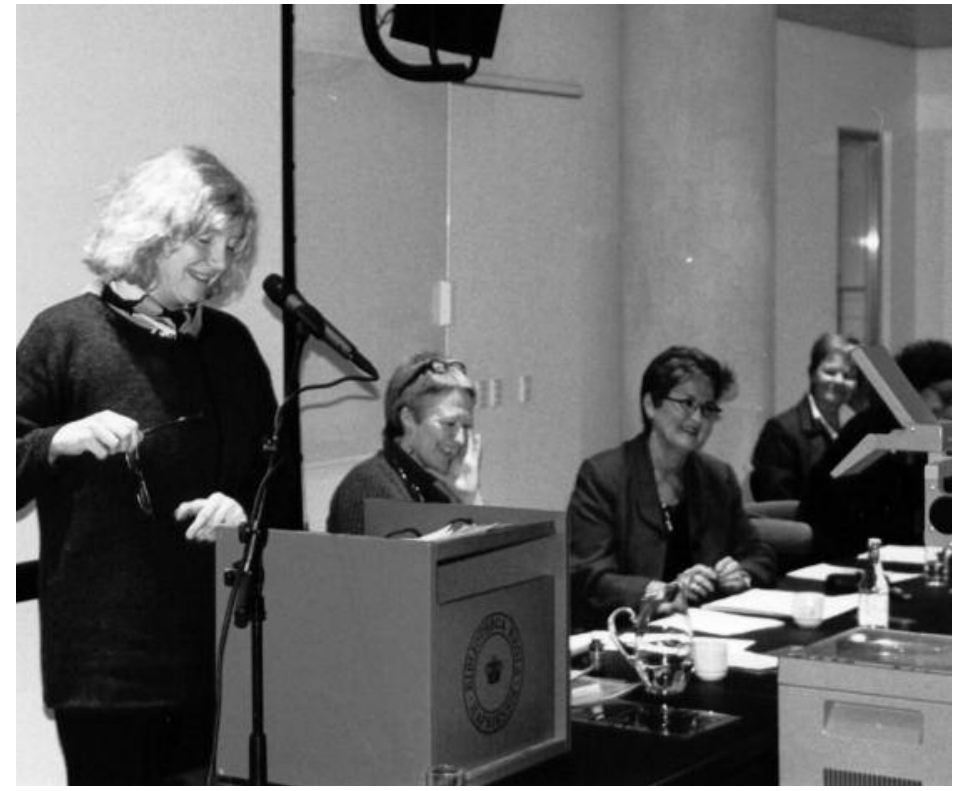

Drude Dablerup.

ville være som at sige til de sorte i Sydafrika under Apartheid: Tal ikke om sorte, tal ikke om, at sorte mennesker er undertrykte. Dermed bidrager I til at konstruere 'den sorte', en fastlåst kategori, som I jo netop har som mål at komme bort

\section{Sverige kontra Danmark}

Når man som jeg arbejder på en institution, nemlig på Statsvetenskapliga Institutionen ved Stockholms Universitet, hvor to professorer ud af fem er kvinder og tilmed kønsforskere, ja så ser sagen ganske an- 
derledes ud. Så er kønsforskningen pr. definition "mainstream". Det er klart en privilegeret situation, som i dag kun genfindes få steder $\mathrm{og}$ kun på enkelte institutioner. Tema Genus ved Linköping Universitet er et andet helt nyt eksempel. Ja, dette er måske slet ikke eksempler på mainstreaming, men tværtimod på den større anerkendelse af køns(genus-) perspektivet som et selvstændigt forskningsområde, som findes i Sverige i dag sammenlignet med Danmark.

Der er generelt en forbavsende forskel på diskursen om køn i Danmark og Sverige i dag. Det er som om Danmark efter de hede dage i 1970'erne og begyndelsen af 1980'erne, hvor vi var de beundrede $\mathrm{i}$ Norden, nu er gået i stå. En ny diskurs, eller forforståelse om man vil, er kommet frem i Danmark, nemlig at nu er lige- stilling da opnået. Ja, visse plæderer for, at kvinderne er begyndt at "dominere". Det støttes stort set alene af det faktum, at der nu er ca.55\% kvinder, der studerer medicin og jura, og at de fleste markarbejdere i den sociale sektor er (lavtlønnede) kvinder. Men langt den overvejende del af de ledende stillinger inden for forskningen og i disse erhverv, er fortsat besat af mænd. 55\% på medicinstudiet er "kvindedominans", mens 66\% mænd i Folketinget er "næsten ligestilling"!

Sammenligningen mellem Sverige og Danmark afslører, hvorledes diskursen om køn kan være relativt autonom $\mathrm{i}$ forhold til de faktiske forhold. Den svenske diskurs om "kvinnoförtryck" er jo ikke blevet så meget stærkere end den danske, fordi svenske kvinder har mindre i løn end de danske, bliver oftere voldtaget, eller fordi der er færre andel kvinder i toppolitiken.

Det er vigtigt at påpege, at den relative fremgang, der er i gang for kønsforskningen i Sverige, ikke er kommet, fordi man i Sverige er holdt op med at tale om kvinder og kvindeundertrykkelse. Tværtimod. Man kunne opkaste den tese som står i modstrid med hvad andre har sagt på dette seminar - at de svenske kønsforskeres insisteren på en radikal kritik af kvinders forhold og at den statslige ligestillingspolitik har haft selvstændig betydning for, at den svenske jämställdhetspolitik, trods dens mangler, er mere vital, og at debatten om kvinders forhold er mere levende i Sverige end i gamle Danmark.

\section{Drude Dablerup, professor ved Stockbolms Universitet}

Fra udstillingen 'Konsforskningens historie i 30 år', Det Kongelige Bibliotek.

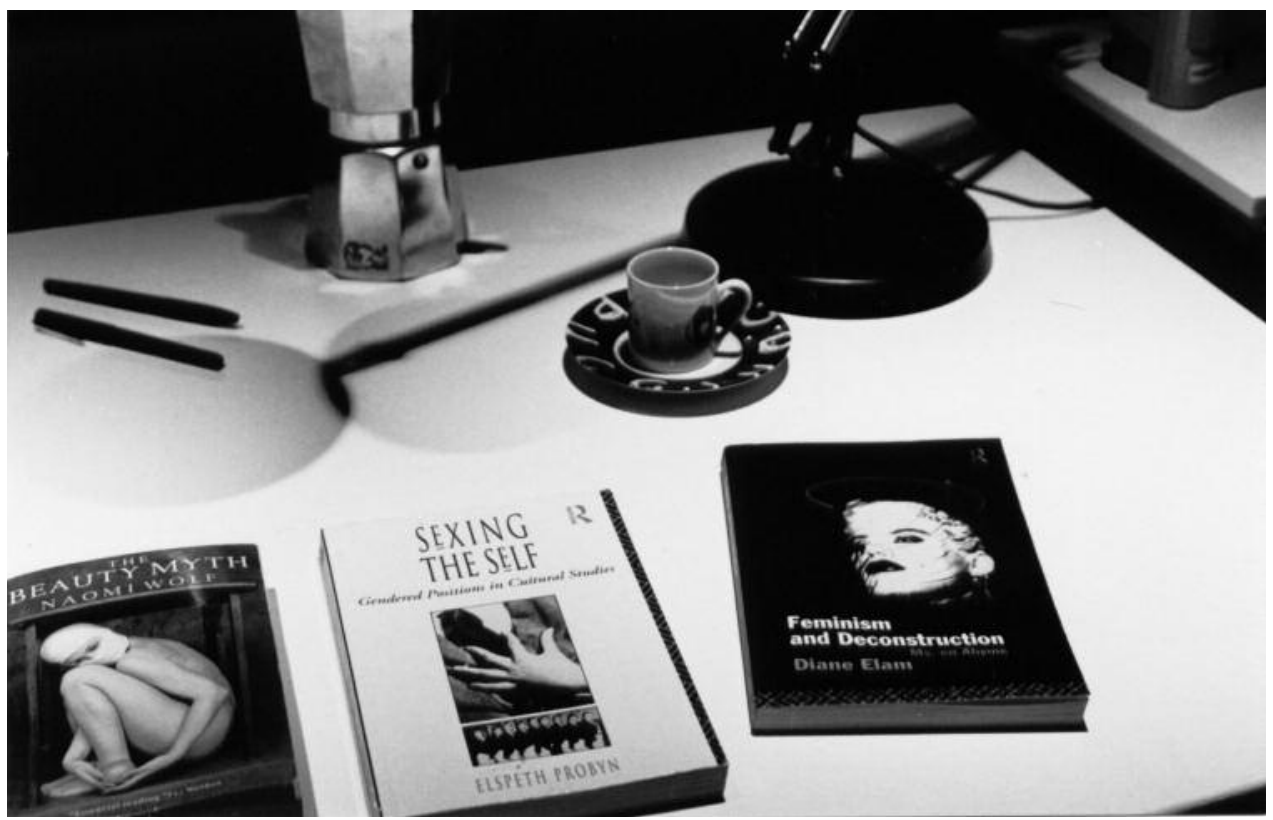




\section{Mainstreaming - et redskab til ligestilling i universitetsverdenen}

Af Jytte Andersen,
Ligestillingsminister

Sligger det mig naturligvis stærkt på sinde at intensivere ligestillingsarbejdet - og det glæder mig, at fă lov til at deltage i diskussionen om den fremtidige indsats på forskningsområdet.

Det er bedrøveligt, at være vidne til den mangel på prioritering som området har været underlagt i løbet af det sidste årti. Det er ligeledes bedrøveligt at være vidne til den åbenlyse mangel på kvindelige forskere på universiteterne - og specielt manglen på kvindelige professorer.

Som det ser ud lige nu, så består hovedparten af det fastansatte videnskabelige personale ved de højere læreanstalter af mænd. For professorerne udgjorde kvinderens andel kun ca. $6 \%$ ved sidste opgørelse.

Jeg bliver nødt til at spørge: Hvorfor er så få kvinder ansat som undervisere ved landets højere læreanstalter - når kvinderne samtidig udgør en så stor andel af landets studerende ? (Ved de lange uddannelser var tallet $50 \%$ i 1998 og antallet af kvindelige Ph.d. studerende udgjorde i 1999 ca. 40 $\%)$.

Min kollega Birthe Weiss har bl.a. krævet af universiteterne at de tager ligestilling med i deres kontrakter og jeg kan kun støtte hende i dette initiativ. Jeg mener også, at der samtidig må udarbejdes kon- krete handlingsplaner for ligestilling med veldefinerede mål og midler. Og der er helt nødvendigt at inddrage alle niveauer - lige fra de studerende til læreanstalternes ledelse.

\section{Mainstreaming af kønsforskningen}

I dag sætter vi fokus på mainstreaming og kønsforskning. Det er vigtigt at sikre fornyelse af kønsforskningen her i det nye århundrede - vigtigt at sikre implementeringen af mainstreamingstrategien. Mainstreaming indikerer en vigtig $æ n-$ dring i ligestillingsarbejdet.

Med mainstreaming er ligestillingsarbejdet på vej over i en ny fase. En fase som betyder, at ligestilling ikke længere er et særskilt spørgsmål ved siden af andre spørgsmål. Men at ligestilling derimod er et emne, der skal tages hensyn til $i$ alle relevante sammenhænge.

Mainstreamingstrategien betyder derfor også, at vi skal til at arbejde med ligestilling på en ny måde. Tiden er nu inde til at gøre ligestilling til et reelt samfundsanliggende.

En af forudsætningerne for at intensivere arbejdet med ligestilling er selvfølgelig, at der sker en akkumulation af viden på området - og her spiller kønsforskningen en vigtig rolle.

Mainstreaming betyder en udbredelse af ansvaret for ligestilling - og mainstreaming betyder, at alle fagområder derfor skal være i besiddelse af relevant viden om køn på deres område.

Det betyder også, at fagområderne skal holdes fast på sektoransvaret. Og her er jeg net- op inde på en af risiciene ved mainstreaming. For gennemførelsen af mainstreaming forudsætter en politisk ansvarlig minister - en ansvarlig ressortminister.

Ressortansvaret gør det vigtigt, at kønsforskningen kobler sig endnu tættere op af alle fagområder. Kapaciteten på såvel naturvidenskabelige, humanistiske og samfundsvidenskabelige fag skal øges - og kønsforskerne skal offensivt gå i clinch med fagspecialisterne.

Jeg mener, at kønsforskningen må se det som en selvstændig opgave at udlære fagfolk i alle kategorier til at tænke køn og til at foretage kønsanalyse. Kønsanalysen skal ikke være forbeholdt kønsforskerne - for behovet er meget stort. Det er derfor vigtigt at få udlært så mange som mulig - og på det højeste mulige niveau.

Jeg vil opfordre kønsforskningen til at anstrenge sig for at tænke i praktisk politik. I skal pirre debatten. Der bliver brug for løsningsforslag, og kønsforskningen har den nødvendige ekspertise og erfaring. Denne ekspertise og erfaring må aktiveres. Og jeg mener, det er kønsforskernes opgave ikke blot at fremlægge nye erkendelser - men også at fremlægge overvejelser om, hvordan vi reelt fremmer ligestillingen.

Jeg vil gerne give et eksempel på et praktisk problem i den danske hverdag, nemlig transport: Danske kvinder og mænd bruger hver næsten en time om dagen til transport men mændene flytter sig i gennemsnit $37 \mathrm{~km}$ og kvinder kun $28 \mathrm{~km}$. Det afspejler, at mænd 
bruger hurtigere transport midler - og at det overvejende er kvinder der anvender de offentlige transportmidler.

Dette betyder, at en diskussilig transport også er et kønspolitisk spørgsmål. Bedre offentlig transport betyder således noget andet for kvinders hverdag end for mænds. Og i betragtning af børnefamiliernes generelle problem med at få tiden til at slå til, så synes jeg, det er et væsentlig område for kønsforskningen.

Er kønsforskerne klar til sammen med trafikforskerne at komme med bud på de ligestillingspolitiske konsekvenser og muligheder af transportmønstrene? Eller måske sammen med byplanlæggerne ?

Dette er et praktisk eksempel på mainstreaming - at tænke i køn på alle områder, at udføre kvalificeret forskning på alle samfundets områder. on om privatbilisme og offent-

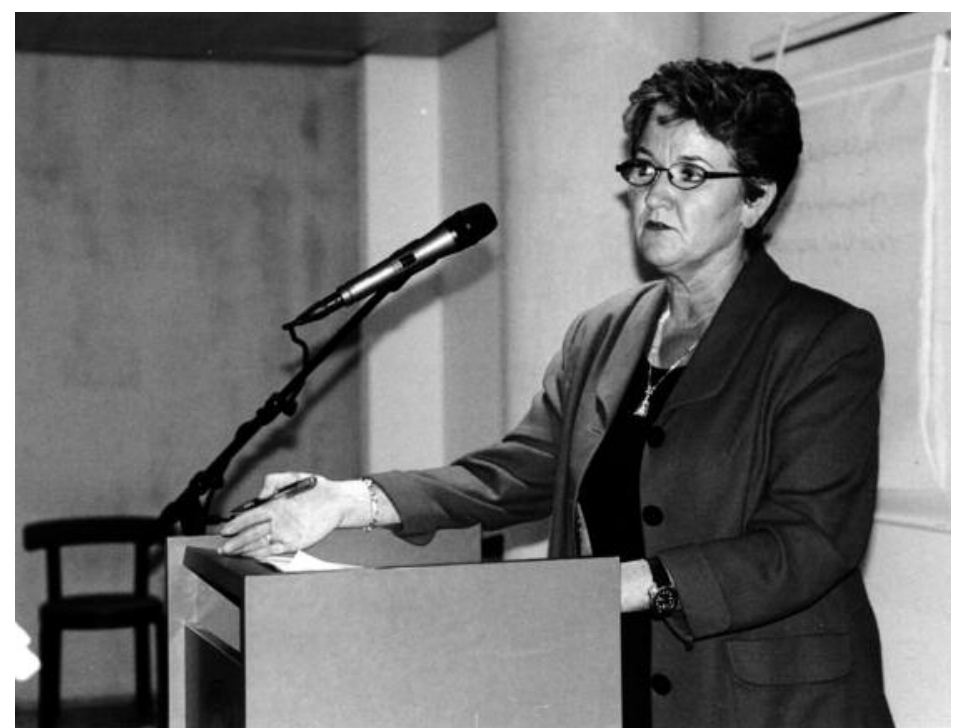

Ligestillingsminister Jytte Andersen.

\section{Afrunding}

Jeg mener, at kønsforskningen bør bruge mainstreamingstrategien til at bide sig fast $\mathrm{i}$ støvede, mandsdominerede universitetskroge og kræve af dem, at de ved nok om køn.

For hvis ikke universiteterne
Jytte Andersen i samtale med Drude Dablerup.

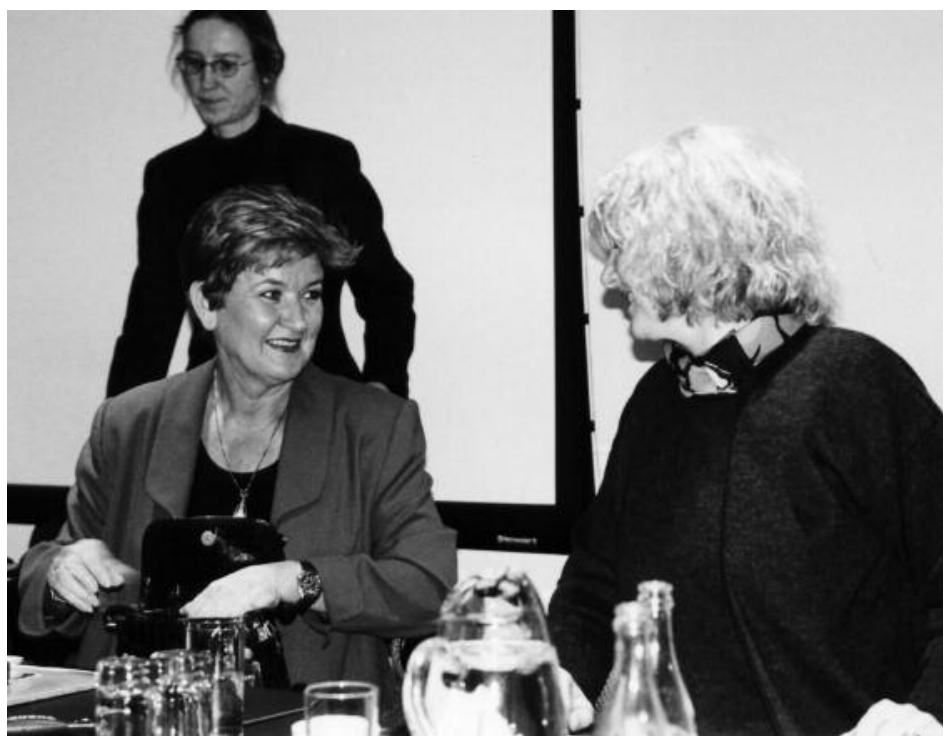

kan præsentere viden om begge køns livsvilkår og udfoldelsesmuligheder, lider samfundet et tab af ressourcer.

Mit bidrag til, at der forsat og gerne i højere grad end nu - eksisterer livskraftig kønsforskning, bliver at stille de provokerende, men helt nødvendige spørgsmål. Jeg vil holde mine ministerkolleger til ilden - og jeg vil modernisere ligestillingsarbejdet, med min egen afdeling og med videnscentret. Oprettelsen af et selvstændigt videnscenter vidner om nye tider - og om den bevågenhed området har fra politisk side.

Mit bidrag bliver at sørge for, at behovet for viden står klart. Jeres bidrag bliver at hjelpe med til at frembringe den viden.

Tak for ordet.

Jytte Andersen MF, Ligestillingsminister 


\section{Forskningsrådene og ligestillingen}

\section{Af Ning de Coninck-Smith}

T1997 var Jytte Hilden vært for en konference på Ålborg Universitet om ligestilling på universiteterne. Til lejligheden var udarbejdet det såkaldte 11 punkts program, som bl.a. gjorde ligestillingen til et ledelsesansvar, stillede krav om, at ligestillingen burde gennemføres på alle niveauer, og at der skulle oprettes flere kvindelige professorater (med baggrund i en situation, hvor kun $6 \%$ af professorerne er kvinder). Af programmet fremgik endvidere, at forskning og familie skal kunne sameksistere. Programmet lagde desuden op til, at kønsforskningen skulle opprioriteres.

Ser vi på de seks statslige forskningsråd og forskningsforum kan vi to år senere konstatere, at programmet har haft en vis effekt - især på det ligestillingsmæssige område. Med Statens Jordbrugsvidenskabelige forskningsråd i spidsen er rådene $\mathrm{i}$ færd med at udarbejde det man kunne kalde "ligestillingspolitiske retningsliner", som skal sikre lige muligheder for begge køn, herunder en opmærksomhed på at kvinder og mænd traditionelt har forsket i forskellige emner.

Rådene gennemfører også årlige screeninger af deres uddelinger, for at sikre sig mod kønslige skævvridning. Og på det allerseneste er udkommet SSF's undersøgelse af køn og bevillinger. Den viser - groft forenklet -, at kvinder har en god succesrate på frimidler og på mindre ansøgninger, dvs. rejser, oversættelser o.lign., men en meget ringe succesrate på større programmer.

I forbindelse med udarbejdelsen af disse "ligestillingspolitikker" har tallet en tredjedel udkrystaliseret sig som en funktionel variabel, hvad enten det handler om besættelse af udvalg eller uddeling af midler, forstået på den måde - her citeret fra SHF's "Politik vedrørende ligestilling mellem kønnene":

“... at andelen af kvinder og andelen af mænd begge skal være over en tredjedel på alle områder, hvor dette mål kan nås uden at gå på akkord med lament gældende kvalitetskriterier.”

Forskningsforum diskuterer for tiden - emnet behandles på ny på forums møde i marts 2000 - om det er muligt, at lave et fælles regelsæt for alle råd, incl. forum.

Endelig bør der gøres opmærksom på det store tværsrådslige forskningsprojekt "Kønsbarrrierer i forskning", som ventes afsluttet i år. Resultater herfra tyder på, at en lang række faktorer spiller ind, når kvinder vælger universitetet fra - eller når universitetet vælger kvinderne fra. Fra kultur, til kønsblindhed og stillingsopslag, der "lukker sig om sig selv" til arbejdsvilkår, usikkerhed, og vanskelighederne ved at forene børn, familie og forskning.

\section{Veje ud?}

Først og fremmest er det vigtigt at være opmærksom på, at det er begrænset, hvor meget rådssystemet i sig selv kan udrette. Vi kan sende signaler, vi kan være frontløbere, men rådene fordeler kun 1/9-del af de statslige forskningsbevillinger. 2/3-del af de eksterne forskningsmidler administeres nemlig af andre ressortministerier end Forskningsministeriet. Efter min overbevisning er disse tal i sig selv et argument for, at ligestilling på universiteterne kræver højere basisbevillinger, så der bliver realiteter i kravet om, at ligestilling er et ledelsesansvar - på alle niveauer.

For det andet, maner SSF i forening med Danmarks Forskningsråds nyligt udgivne rapport om forskningsfinanciering til eftertanke. Hvor SSF konkluderer, at programmerne ikke er attraktive for kvinderne, så konkluderer Danmarks Forskningsråd, at visse af programmerne er så smalle, at der reelt ikke har været konkurrence om pengene. To argumenter, der på forskellig vis taler for at øge andelen af frie midler på bekostning af programmerne.

For det tredje sidder vi med erfaringerne fra Freja, et bevidst forsøg på at give kvindelige forskere bedre muligheder. 327 søgte - 16 projekter fik penge. Endnu er det naturligvis alt for tidligt, at vurdere $\mathrm{i}$ hvilken grad et sådant program rykker ved kønsubalancen på universitetet - ligesom det er vigtigt at gøre sig klart, at det ikke nødvendigvis er de samme virkemidler, som skal $i$ anvendelse alle steder. Det er heller ikke sikkert, at et topstyret virkemiddel har den store effekt, hvis ikke der er resonansbund 
lokalt. Indlejring vil formentlig blive det store problem efterhånden, som de første phd'ere og adjunkter bliver færdige med deres Freja-penge.

Det er min opfattelse at der i forskningsrådssystemet - med ministeren i spidsen - er en anerkendelse af, at programtænk- for det, der mange steder vel kan karakteriseres som "tilfældighedernes hoppen fra sten til sten".

Hvor efterlader det kvinderne? Man kan som bekendt vælge at læne sig tilbage, og mene, at problemet vil løse sig af sig selv - flere kvindelige studerende, flere kvindelige

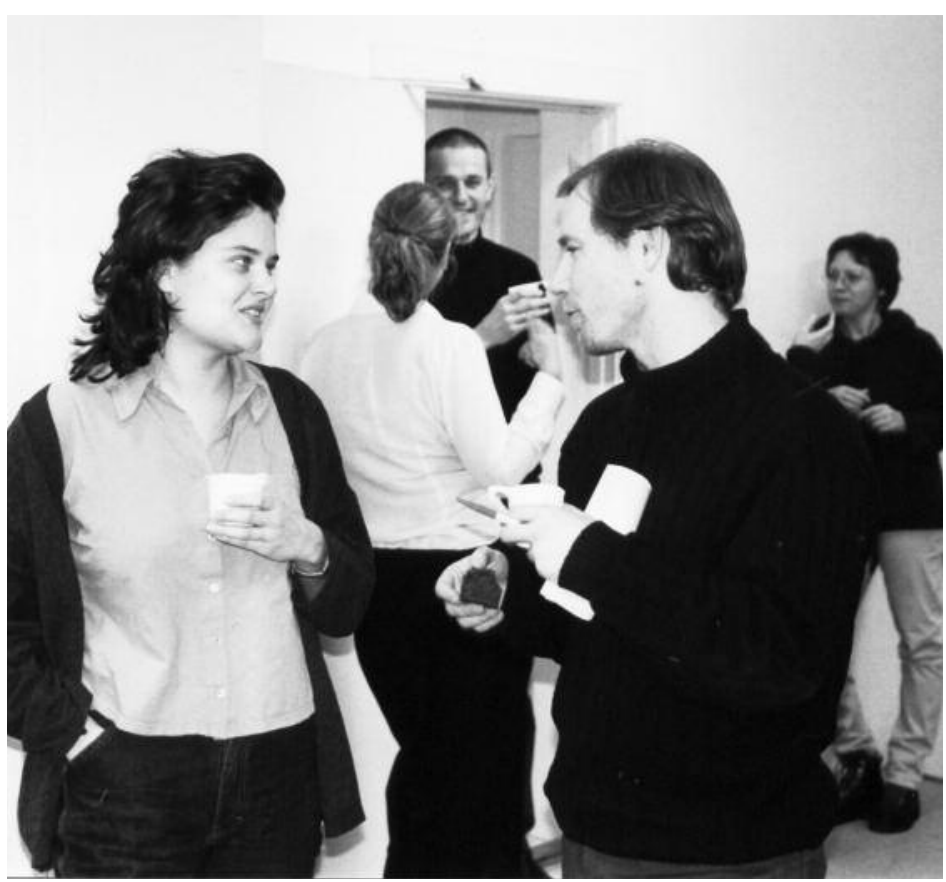

Tilhører ved Kønsforskningsfestivalen.

ningen var gået for vidt, og at rådene må have flere midler stillet til disposition, som de selv kan råde over - enten alene eller et par råd sammen. Samtidig med, at universiteterne bør sikres højere grundbevillinger for at kunne (for)blive attraktive forskningsmiljøer, der kan stå sig i konkurrencen med det private erhvervsliv og får mulighed for at føre en bevidst ansættelsespolitik, frem- phd'ere, flere .... Omvendt viser megen forskning, at kvinderne omkring adjunkttiden støder på et "usynligt glasloft". Derfor er det min opfattelse, at meget kunne tale for, at vi skulle overveje et Freja 2, som var målrettet post doc-niveauet i stil med de stipendier som SSF for nylig har opslået.

Måske skulle man på baggrund af erfaringerne fra Freja 1 lægge midlerne ud i rådene, så de kunne koordineres med de øvrige uddelinger og indgå i rådenes egne stategiplaner.

Personligt har kravet om flere kvindelige professorater ikke min første prioritet. Jeg tror, at "rykket" skal komme nedefra og jeg frygter, at et sådant forslag vil spænde ben for mere tilbundsgående tiltag. Jeg ser heller ikke kønsforskning, som en "løftestang" i sig selv om end jeg naturligvis anerkender den betydning, som kvindekønsforskning har haft på især det humanistiske og samfundsvidenskabelige felt. Jeg så gerne, at kvinde- og kønsforskningen blev en integreret parameter $i$ al anden humanistisk og samfundsvidenskabelig forskning. Som ansat på et center for kulturstudier er det mig helt ubegribeligt, at vi ikke (endnu) har en lektor i kvindeog kønsstudier ansat.

Men først og fremmest tror jeg ikke spørgsmålet om ligestillingen bliver løst, før universiteterne (igen?) fremstår som attraktive arbejdspladser med rum til forskning, karriere, familie og børn. Hvornår eller om - det sker, kan kun fremtiden vise, men jeg mener, at det er en opgave for forskningsrådssystemet at sætte fokus på problemet, ligesom vi også bør gøre vores til at udvikle bevillingsformer, som bedre tilgodeser kvindelige forskere.

Ning de Coninck-Smith Lektor, Center for kultur studier, Syddansk Universitet, Odense. Eksternt medlem af Forskningsforum

\section{Hvad skete der så med} strategiplanerne? 


\section{Af Bente Rosenbeck}

$\int \mathrm{e}$ eg skrev for nogle år siden en anmeldelse af Statens humanistiske Forskningsråds strategiplan 1998-2002 med titlen "Det 21. århundrede: Videnskab-Virkelighed-Vision" i Kvinder, Kon \& Forskning. Jeg var dengang skuffet over, at der ikke stod ret meget om kvinder og køn til trods for, at vi havde gjort os de ihærdigste anstrengelser for at få noget med. Der var nemlig blevet indkaldt interessetilkendegivelser inden planen blev udformet, og kvindeforskningsmiljøerne havde ydet deres bidrag, men uden resultat. $\mathrm{Nu}$, hvor strategiplanerne er opfyldt og pengene givet ud, kan jeg konkludere, at det blev værre, end jeg troede. Kvinde- og kønsforskning blev der som forventet ikke noget af, men desuden gik meget få af de uddelte midler til kvinder, nemlig ca. 11\%. I forbindelse med SHF's strategiplan 1998-2001 er der blevet uddelt 44,7 mill. kr. i 1998. Der blev givet penge til 18 nye projekter, og heraf gik de fire til kvinder. Det svarer meget godt til deres andel af ansøgerne, idet $21 \%$ af de støtteværdige ansøgninger kom fra kvinder. Der er således for få kvinder som søger, og de fik kun godt 4,9 mill. kr., i alt lidt under 11\%. Det er den tredje strategiplan, der nu har nærmet sig sin afslutning, og kvinder er trods alt bedre representeret ved den sidste strategiplan end den første, hvor samtlige fem projekter havde mandlig ledelse.
Jeg har ellers altid været begejstret for strategiplanerne, fordi de er tværfaglige og sprænger den snævre disciplinorienterethed, hvilket burde være en fordel for kvinde- og kønsforskningen. Men jeg må konkludere, at strategiplaner faktisk ikke har været en fordel for kvindelige forskere. De klarer sig langt bedre ved uddelinger af de frie midler. En opgørelse over ansøgninger til og bevillinger fra forskningsrådene i 1996 viste, at de mandlige ansøgere havde en succesrate på $49 \%$ og kvindelige forskere på $36 \%$. SHF havde dog sammen med SNF en relativ høj succesrate for kvindelige ansøgere. Disse opgørelser blev udarbejdet i forbindelse med Jytte Hildens initiativer og 11 punkts programmet i 1996. Siden er det i SHF blevet almindelig at udarbejde statistik i forbindelse med uddelingerne. Af de 339 ansøgninger i 1997 kom 128 (38\%) fra kvindelige forskere. Af de 42 forskere, som modtog støtte var 16 (38\%) kvinder. I 1998, som var året hvor strategimidlerne blev uddelt, var succesraten for kvindelige forskere lidt lavere end i 1997. Af de 359 ansøgninger var 165 (46\%) fra kvindelige forskere. 56 modtog en bevilling, heraf var de 18 (32\%) kvinder. I 1999 ser det igen bedre ud. Ved den ekstraordinære uddeling i sommer gik 14 af 22 projekter til kvinder (kun halvårlige projekter). Ved efterårsuddelingen gik 19 af 32 ph.d.stipendier til kvinder.

Men når det drejer sig om strategiplaner, så løber mændene med det meste. Det er sådan set mærkeligt, når man tænker på, at der i forbindelse med Freja-midlerne var indsendt 68 overvejende store humanistiske projekter. Holder kvinderne sig for meget tilbage, eller har det noget med interesseområder at gøre? Jeg tror både-og. Ved strategisk forskning er emnerne bundne, mens Freja midlerne var frie. Så vil man have flere kvinder ind, så sker det åbenbart bedst gennem frie midler. Eller også må den strategiske forskning opdyrke nogle andre områder. Heine Andersens undersøgelse "Hvad forskes der i", som udkom sommeren 1999, viste, at der åbenbart var sket en skævvridning inden for samfundsvidenskabelig forskning til fordel for politiske og økonomiske emner. Kun én ud af ti forskere beskæftigede sig med, hvad der blev kaldt det civile samfund, herunder forskning om familie, børn, unge, ældre, køn, kultur, medier, kommunikation, religion, fritid, sport og indvandrere, flygtninge, etnicitet. Absolut samfundsrelevante emner som det er vigtigt at forske i, og jeg kan også fortælle, at en gymnasielærer i forbindelse med et historieseminar her i efteråret nævnte, at 90\% af eleverne i gymnasiet skriver historieopgave inden for det civile samfund. Han måtte jo indrømme, at som situationen så ud nu, så var dansklærerne bedre rustet til at undervise $\mathrm{i}$ de emner end historielærerne, som typisk vil være bedre uddannet i politisk og økonomisk historie end i social- og kulturhistorie. Hvis der i fremtiden blev fokuseret lidt anderledes med hensyn til satsningsområ- 
der end hidtil, så ville det også ændre på kønsbalancen.

Flere kvindelige professorer på humaniora er det heller ikke rigtigt blevet til. Selv om humaniora har en tradition for mange kvinder i forhold til andre videnskabsområder, så var der kun 13 kvindelige profes- dig på 13. Ståhles konklusion er, at på humaniora (og naturvidenskab) er kvindeandelen af professoraterne markant lavere i Danmark end i de øvrige nordiske lande. Denne forskel kan have mange årsager, men kan hænge sammen med udviklingen i 1980'erne. Ståhle skriver,
Alder, køn og rekruttering $i$ dansk universitetsforskning fra 1999, synes ikke at rykke noget, i hvert fald er konklusionen, at der kun er en svagt stigende tendens i kvindeandelen, hvilket betyder "at udviklingen mod en mere ligelig kønsfordeling stadig er meget

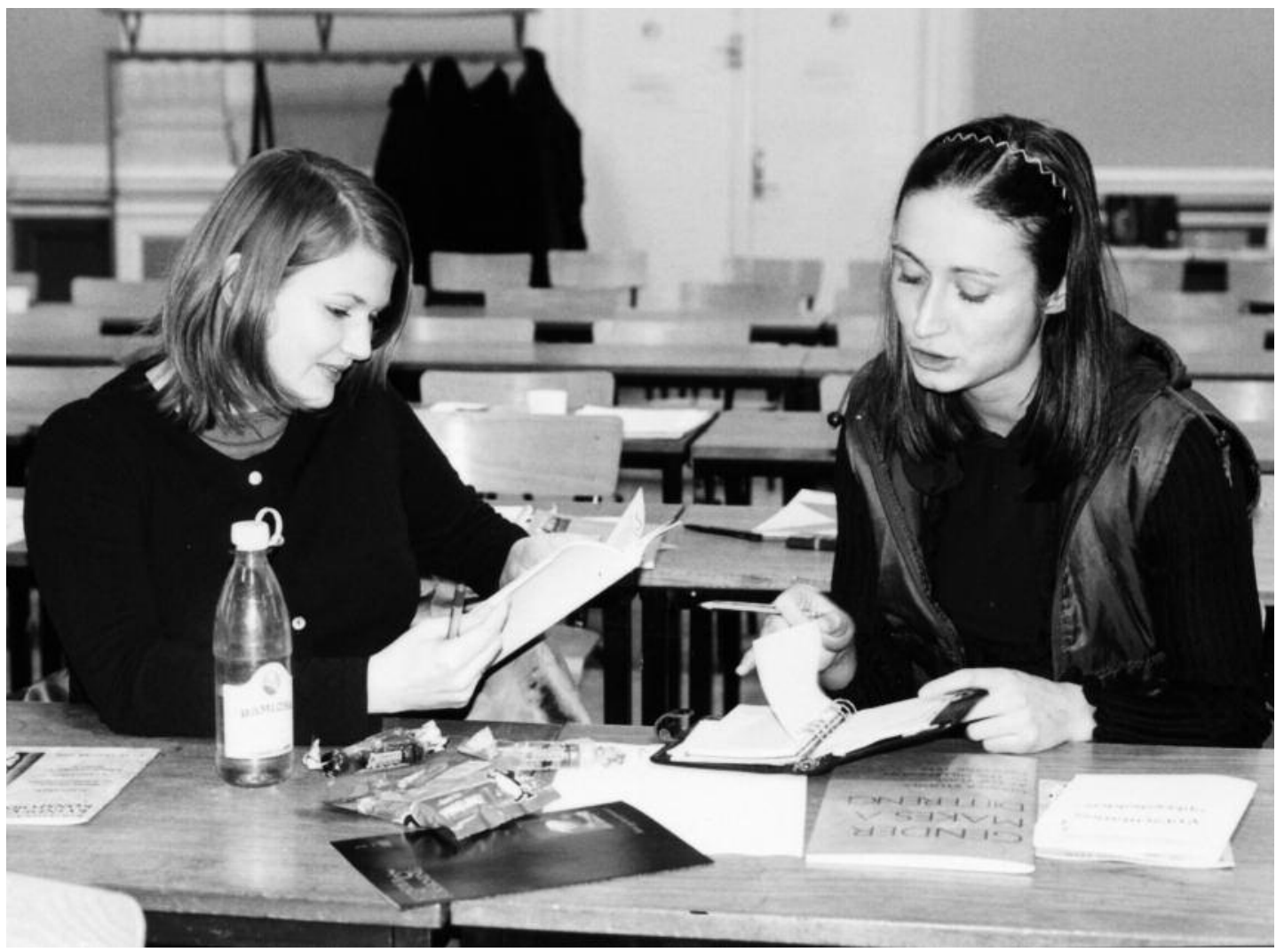

Tilhører ved Kønsforskningsfestivalen.

sorer (10\%) ifølge Bertel Ståhles rapport: Kvinder og mond $i$ dansk universitetsforskning $i$ 1990'erne fra 1998. Politikens undersøgelse fra sommeren 1999 viste, at der var kommet nogle nye til, men der var også gået nogle fra, så tallet lå sta- at "udviklingen i kvindeandelen i perioden 1980-1990 kan betegnes som langsom og negativ" $(1998,35)$. Der blev således ansat meget få kvinder i forbindelse med forskerrekrutteringsplanen i perioden 1985 til 1992. Ståhles nyeste rapport langsommelig på stort set alle niveauer og alle områder, med undtagelse af adjunktkategorien" (19).

På nogle områder går det godt indenfor humaniora på andre mindre godt. Men det skal også gå godt, for at det 
overhovedet kan siges at gå fremad. Bertel Ståhle skriver i rapporten Kvinder og mand $i$ dansk universitetsforskning $i$ 1990'erne, at hvis udskiftningen skal kunne foregå inden for samme tidsrum, som kræves for udskiftningen af det samlede personale (20 til 30 år), så er det nødvendigt, at der "til de ledigblevne stillinger årligt rekrutteres flere kvinder end mænd". Samtidig har kvinder udgjort over $50 \%$ af kandidatproduktionen i 25 år. På Københavns Universitet har den længe ligget mellem $60 \mathrm{og}$ $70 \%$, så kvinderne skal have en stor bid af forskningsmidlerne, for at der kan ske en udligning.

Er der sket noget siden 1994? Dengang valgte regeringen at integrere ligestillingshensynet i "en række initiativer af generel karakter" som undervisningsministeren sagde under en forespørgsel om bedre kønsfordeling blandt ansatte på universiteter m.m. i foråret 1994. Og så gentog han midlerne: ved åbne opslag, ved 600 nye ph.d.-stipendier, ved 200 nye professorater, ved for- bedret orlovsordning for kvindelige forskerstuderende og ved "en klar opfordring til institutionerne om at formulere en personalepolitik, der indeholder en indsats for en mere lige kønsfordeling på alle stillingsniveauer uden at gå på kompromis med kvalitetshensyn". Det er seks år siden, og hvad er der kommet ud af disse initiativer? Ingen ligestillings- og handlingsplaner på universiteterne og heller ikke mange flere professorer.

Desuden er det et problem for kønsbalancen, at væksten i forskningen her i 1990'erne især har ligget inden for den programlagte forskning, for her er kvinder meget dårligt repræsenteret. Det vil sige, at kvinders andel er meget lav i de aktiviteter, som er vokset mest, og havde vi ikke fået Freja-projektet, havde det været rent galt. Så her må man opfordre til, at man i de kommende år er opmærksom på køn, både når det drejer sig om strategimidler og programmidler. Det gxlder mainstreaming. Kønsaspektet bør ind- drages ved planlægningen af forskningsinitiativer, af videnskabelige prioriteringsområder og forskningsprogrammer. Når der vedtages større forskningsprogrammer og satsningsområder, bør kønsaspektet inddrages både i prioriteringen af forskningsfelter og i overvejelserne over deltagende forskere. Det er vigtigt at udnytte den berigelse, som en øget deltagelse af kvinder i forskningen efter min mening vil indebære. Ved at sikre en bredest mulig rekrutteringsbasis (både med hensyn til køn, klasse og etnicitet) udnyttes forskningsressourcerne optimalt. Ligestilling kan medvirke til at udvide den talentmasse, der er til rådighed, og bliver derved et effektivt middel til at bevare og udvikle forskningens kvalitet. Inddragelse af flere menneskelige ressourcer vil bidrage til at skabe større mangfoldighed af perspektiver i forskningen.

Bente Rosenbeck, dr.phil, lektor ved Center for kvinde- og kønsstudier, Københavns Universitet 